\title{
FAKTOR-FAKTOR INTERNAL DAN EKSTERNAL YANG BERHUBUNGAN DENGAN PEMILIHAN PASAR PETANI MANGGA
}

\section{THE RELATIONSHIP BETWEEN INTERNAL AND EXTERNAL FACTORS WITH MARKET SELECTION OF MANGO FARMERS}

\author{
Elly Rasmikayati*1, Aurelia Fadhilah Sari ${ }^{1}$, Rani Andriani Budi Kusumo ${ }^{1}$, \\ Bobby Rachmat Saefudin ${ }^{2}$, Nur Syamsiyah ${ }^{1}$ \\ ${ }^{1}$ Fakultas Pertanian, Universitas Padjadjaran, Jl. Ry Bandung-Sumedang KM.21 Jatinangor, 45363 \\ ${ }^{2}$ Fakultas Pertanian, Ma'soem University, J1. Raya Cipacing No. 22 Jatinangor, 45363 \\ *E-mail: e.rasmikayati@unpad.ac.id \\ (Diterima 09-07-2020; Disetujui 24-07-2020)
}

\begin{abstract}
ABSTRAK
Pemilihan pasar yang dijadikan mitra oleh petani didasari oleh kemampuan petani untuk menarik perhatian pembeli. Namun, pada kenyataannya sebagian besar petani mangga memiliki ketergantungan yang tinggi untuk menjual hasil panennya kepada tengkulak. Penelitian ini bertujuan untuk menganalisis faktor-faktor internal dan faktor-faktor eksternal yang berhubungan dengan pemilihan pasar bagi petani mangga. Penelitian ini merupakan penelitian kuantitatif yang dilakukan di Kecamatan Sedong, Kabupaten Cirebon, Jawa Barat. Metode penelitian menggunakan metode survey. Sampel penelitian diambil menggunakan teknik simple random sampling sedemikian rupa sehingga diperoleh ukuran sampel sebanyak 50 orang. Alat analisis data yang digunakan adalah analisis crosstabulation. Hasil penelitian menunjukkan bahwa faktor internal yang memiliki hubungan berbanding lurus dengan pemilihan pasar adalah tingkat pendidikan, jumlah pohon, kepemilikan transportasi, dan keaktifan dalam kelompok tani; sedangkan faktor internal yang memiliki hubungan berbanding terbalik dengan pemilihan pasar adalah umur dan pengalaman usahatani. Faktor eksternal yang memiliki hubungan berbanding lurus dengan pemilihan pasar adalah jarak ke pasar, waktu tempuh ke pasar, dan kontribusi pemerintah. Sementara faktor internal berupa tingkat kepercayaan, akses informasi, dan keaktifan dalam mengikuti penyuluhan, serta faktor eksternal berupa penyelenggaraan penyuluhan tidak memiliki hubungan dengan pemilihan pasar.
\end{abstract}

Kata kunci: Faktor internal, faktor eksternal, pemilihan pasar, pemasaran mangga, agribisnis

\begin{abstract}
The selection of the market that partners with farmers is based on the ability of farmers to attract the attention of buyers. But in reality, most mango farmers have a high dependency to sell their harvest to middlemen. This study aims to analyze internal and external factors related to market selection for mango farmers. This research is a quantitative study conducted in Sedong District, Cirebon Regency, West Java. The research method uses the survey method. The research sample was taken using a simple random sampling technique such that a sample size of 50 people was obtained. The data analysis tool used is crosstabulation analysis. The results showed that internal factors that have a directly proportional relationship to market selection are the level of education, number of trees, ownership of transportation, and activeness in farmer groups, while internal factors that have an inverse relationship with market selection are age and farming experience. The eexternal factors that have a directly proportional relationship to market selection are distance to market, travel time to market, and government contribution. While internal factors such as level of trust, access to information, and activeness in participating in counseling, and external factors such as conducting counseling have no relationship with market selection.
\end{abstract}

Keywords: Internal factors, external factors, market selection, mango marketing, agribusiness 


\section{PENDAHULUAN}

Mangga (Mangifera indica L.) merupakan salah satu komoditas unggulan Indonesia pada subsektor hortikultura. Indonesia menempati peringkat kelima sebagai produsen mangga terbesar pada tahun 2016, setelah India, Tiongkok, Thailand, dan Meksiko dengan total produksi sebesar 2,18 juta ton (Pariona, 2018). Berdasarkan data Direktorat Jenderal Hortikultura dalam Elfadina dkk. (2019), komoditas mangga pada tahun 2017 menempati urutan kedua dengan total produksi sebesar 2,2 juta ton atau menyumbang sebesar 11,22 persen dari total produksi buah di Indonesia.

Jawa Barat memiliki produksi benih tanaman mangga bersertifikasi yang lebih besar dibandingkan Provinsi Jawa Timur dan Jawa Tengah, yaitu dengan jumlah lebih dari satu juta pohon, sedangkan Jawa Timur hanya sebanyak 178.061 pohon dan Jawa Tengah sebanyak 29.601 pohon (Direktorat Jenderal Hortikultura, 2015 dalam Kusumo dkk., 2018). Varietas yang dikembangkan di Jawa Barat pun lebih beragam, yaitu terdapat varietas mangga Arumanis, Gedong, Gedong Gincu, Dermayu, dan Golek (Anugrah, 2016). Saat ini, pemerintah Jawa Barat menjalin kerja sama dengan pemerintah Jepang terkait perdagangan mangga gedong gincu karena tingginya minat masyarakat Jepang terhadap mangga gedong gincu (Rasmikayati dkk., 2020).

Tabel 1. Produksi Mangga (Ton) Menurut Kabupaten Sentra di Jawa Barat Tahun 2015- 2017

\begin{tabular}{|c|c|c|c|}
\hline \multirow{3}{*}{ Kabupaten } & \multicolumn{3}{|c|}{ Produksi Mangga (Ton) } \\
\hline & \multicolumn{3}{|c|}{ Tahun } \\
\hline & 2015 & 2016 & 2017 \\
\hline Indramayu & 68.737 & 90.644 & 77.474 \\
\hline Majalengka & 64.395 & 37.529 & 60.064 \\
\hline Cirebon & 37.443 & 31.086 & 39.152 \\
\hline Kuningan & 32.109 & 12.920 & 29.822 \\
\hline Sumedang & 23.491 & 23.403 & 28.385 \\
\hline Jumlah & 226.175 & 195.581 & 234.896 \\
\hline Jawa Barat & 310.226 & 260.106 & 325.548 \\
\hline
\end{tabular}

Dari 27 kabupaten dan kota penghasil mangga di Provinsi Jawa Barat, terdapat lima kabupaten sentra mangga yang berpotensi untuk dikembangkan, yaitu Kabupaten Indramayu, Cirebon, Majalengka, Kuningan, dan Sumedang. Mangga gedong gincu merupakan salah satu varietas unggulan yang dikembangkan di Jawa Barat dan memiliki harga jual tertinggi di Indonesia (Rasmikayati, 2018). Menurut Deliana (2011), mangga gedong gincu dari Cirebon lebih diminati konsumen dibandingkan dengan kabupaten dengan produksi mangga terbesar di Jawa Barat, yaitu Indramayu (Tabel 1). Hal ini dikarenakan mangga gedong gincu 
memiliki bentuk lebih bulat, warna lebih menarik, dan aroma yang lebih tajam.

Kecamatan Sedong merupakan salah satu kecamatan sentra penghasil mangga di Kabupaten Cirebon dengan peningkatan produksi mangga yang cukup signifikan jika dilihat dari tahun 2014 yang hanya mampu memproduksi sebanyak 823 ton, namun masih terkendala dengan masalah pemasaran mangga yang masih banyak melalui tengkulak (Sari dkk., 2019).

Kegiatan pemasaran mangga memiliki keterkaitan dengan pemilihan pasar oleh petani mangga. Pemasaran mangga akan menguntungkan bagi petani jika mereka bebas dalam menentukan salah satu dari berbagai pilihan pasar yang ada dan memperoleh keuntungan yang semaksimal mungkin. Selain itu, jika petani memiliki posisi yang kuat dalam menentukan harga dan keadaan harga pasar tetap stabil, petani lebih termotivasi untuk memenuhi kuantitas dan kualitas mangga secara kontinu, sehingga dapat meningkatkan produktivitas mangga. Dengan tingkat produktivitas dan pendapatan yang tinggi, kesejahteraan petani dapat meningkat.

Namun pada kenyataannya, sebagian besar petani mangga memiliki ketergantungan yang tinggi untuk menjual hasil panennya kepada tengkulak. Hal ini dikarenakan keterbatasan petani terhadap informasi pasar dan mengakses modal. Walaupun lebih merugikan di sisi petani, mereka tetap bersedia bermitra dengan tengkulak karena mampu memenuhi kebutuhannya dalam kondisi darurat. Di samping posisi petani yang lemah di pasar, keterbatasan modal yang dimiliki menjadi hambatan dalam upaya meningkatkan produktivitas mangga.

Pemilihan pasar yang dijadikan mitra oleh petani didasari oleh kemampuan petani untuk menarik perhatian pembeli. Terdapat faktor-faktor yang mempengaruhi petani dalam memilih pasar, baik dari faktor internal, maupun faktor eksternal. Penelitian ini bertujuan untuk menganalisis hubungan antara faktor internal dan faktor eksternal dengan pemilihan pasar bagi petani mangga di Kecamatan Sedong, Kabupaten Cirebon.

\section{METODE PENELITIAN}

\section{Tempat dan Waktu Penelitian}

Objek penelitian ini adalah hubungan faktor-faktor internal dan eksternal dengan pemilihan pasar oleh petani mangga di Kecamatan Sedong, Kabupaten Cirebon, Jawa Barat. 


\section{Desain Penelitian}

Dalam penelitian ini, desain penelitian yang digunakan adalah penelitian kuantitatif. Desain penelitian kuantatif mengolah data berupa angka untuk dapat mengeneralisasi hasil penelitian pada suatu populasi (Mulyadi, 2011).

\section{Variabel Penelitian}

Faktor yang mempengaruhi petani memilih pasar, meliputi berbagai alasan petani mengapa menjual hasil panennya kepada tengkulak, pedagang besar, pedagang pengecer, maupun langsung kepada konsumen akhir. Faktor-faktor tersebut dapat dilihat dari:

1) Faktor internal, meliputi karakteristik petani yang mempengaruhi dalam pemilihan pasar.

a) Akses informasi, yaitu kemampuan petani dalam memperoleh informasi pasar dan harga.

b) Tingkat kepercayaan, menunjukkan bagaimana petani percaya untuk bergantung kepada pembeli dan siap menerima segala risiko yang mungkin akan dihadapi.

c) Kepemilikan sarana transportasi, dibedakan menjadi milik sendiri dan sewa dalam mendukung proses pengangkutan hasil panen dan pemasaran. d) Tergabung dalam kelompok tani, melihat apakah petani mangga merupakan anggota dari suatu kelompok tani yang terdapat di daerahnya.

e) Keaktifan dalam kelompok tani, menentukan apakah keanggotaan petani berbanding lurus dengan kehadiran dan kontribusi dalam kelompok tani.

f) Keaktifan dalam mengikuti penyuluhan, menunjukkan intensitas petani dalam menghadiri kegiatan penyuluhan yang diselenggarakan oleh pihak Penyuluh Pertanian Lapangan (PPL).

2) Faktor eksternal, yaitu faktor yang berasal dari luar diri petani.

a) Jarak dari lahan ke pasar, yaitu jarak yang perlu ditempuh oleh petani dari lahan mangga ke pasar atau tempat bertemu dengan pembeli.

b) Waktu tempuh ke pasar, yaitu waktu yang perlu dihabiskan oleh petani dalam melakukan pengangkutan hasil panen ke pasar atau tempat bertemu dengan pembeli.

c) Penyelenggaraan penyuluhan, yaitu kontribusi dari dinas pertanian daerah setempat dalam upaya meningkatkan kemampuan petani di bidang usahatani maupun pemasaran. 
d) Kontribusi pemerintah, meliputi bantuan pemerintah kepada petani dalam pemberian input produksi dan pinjaman modal.

\section{Teknik Penarikan Sampel}

Sampel diambil menggunakan teknik samping berpeluang (probability sampling) yaitu dengan menggunakan teknik simple random sampling. Populasi dalam penelitian ini adalah petani mangga di Kecamatan Sedong, Kabupaten Cirebon yang masih aktif dalam menjalankan usahatani mangga dan tidak menyewakan seluruh lahan atau pohon mangganya kepada pihak lain berukuran 100 orang dan tingkat presisi yang ditetapkan adalah 10\%. Berdasarkan rumus slovin, ukuran sampel $(n)$ yang diperoleh adalah sebagai berikut:

$\mathrm{n}=\frac{100}{1+100\left(0,1^{2}\right)}=50$ orang

\section{Rancangan Analisis Data}

Analisis crosstabulation digunakan untuk melihat hubungan antara faktorfaktor internal dan faktor-faktor eksternal dengan pemilihan pasar oleh petani mangga di Kecamatan Sedong.

\section{HASIL DAN PEMBAHASAN}

Setiap petani memiliki tujuan pasar yang berbeda dalam menjual hasil panen mangga. Petani dapat menjual hasil panen mangga kepada satu tujuan pasar atau lebih. Pemilihan pasar ditentukan dari faktor internal yang berada dalam diri petani mangga ataupun faktor eksternal yang berasal dari luar diri petani. Faktor internal yang dapat mempengaruhi pemilihan pasar bagi petani mangga antara lain umur, pengalaman usahatani, tingkat pendidikan, Saluran pasar yang dituju oleh petani jumlah pohon, tingkat kepercayaan, akses informasi, kepemilikan transportasi, keikutsertaan dalam kelompok tani, keaktifan dalam kelompok tani, dan keaktifan dalam mengikuti penyuluhan. Sementara faktor eksternal yang mempengaruhi antara lain jarak ke pasar, waktu tempuh ke pasar, penyelenggaraan penyuluhan, dan kontribusi pemerintah.

\section{Hubungan antara Faktor Internal dengan Pemilihan Pasar Petani Mangga}

Faktor internal merupakan faktor yang dapat mempengaruhi suatu hal yang berasal dari dalam diri pelaku. Dalam penelitian ini, faktor internal yang dimaksud adalah faktor yang berasal dari masing-masing petani mangga yang dapat memiliki pengaruh terhadap pemilihan pasar untuk menjual hasil panen mangga. Faktor tersebut dapat dilihat dari karakteristik diri petani, 
karakteristik usahatani, maupun komponen lainnya. Adapun faktor internal yang mempengaruhi petani mangga dalam memilih pasar terangkum pada Tabel 2.

\section{Umur}

Umur petani memiliki hubungan yang berbanding terbalik antara pemilihan pasar dalam menjual hasil panen mangga. Semakin tua umur petani, pasar yang dituju oleh petani mangga di Kecamatan Sedong semakin sedikit (Tabel 2). Petani yang berusia lebih tua tidak ingin memilih lembaga pemasaran yang menimbulkan risiko ketidakpastian pasar. Oleh karena itu, mereka lebih memilih tengkulak dan koperasi dalam menjual hasil panen mangga (Maina, 2015).

Petani mangga di Kecamatan Sedong umumnya telah membentuk hubungan kebiasaan dengan tengkulak sejak awal melakukan usahatani. Besarnya keuntungan yang diambil oleh tengkulak pun tidak menjadi permasalahan bagi mereka karena menurutnya hal itu memang hak yang dapat dirasakan oleh tengkulak. Walaupun dikatakan jika petani mangga memilih tengkulak akan memperoleh keuntungan yang lebih sedikit, tetapi mereka tidak perlu mencari pasar atau pembeli baru yang belum secara pasti diketahui tingkat keuntungan yang akan diperoleh.

Sementara itu, petani yang berusia lebih muda menurut Marenya dan Barrett (2007) lebih berpartisipasi di pasar karena ingin menerima ide-ide baru. Petani yang menyukai risiko cenderung mencari pasar yang menguntungkan, meskipun pada awalnya harus mengalami ketidakpastian pasar. Berdasarkan Tabel 2, petani mangga di Kecamatan Sedong yang memiliki tujuan pasar lebih banyak justru pada kelompok umur 46-64. Akan tetapi, terdapat juga petani mangga pada kelompok umur 31-45 yang pernah mencoba memperluas pasarnya hingga ke ritel modern, meskipun tidak berlangsung lama.

\section{Pengalaman usahatani}

Selain umur petani, pengalaman usahatani merupakan faktor internal yang memiliki hubungan berbanding terbalik dalam pemilihan pasar. Hal ini memiliki arti bahwa semakin sedikitnya pengalaman dalam menjalankan usahatani mangga, pasar yang dituju justru akan semakin banyak. Petani mangga di Kecamatan Sedong yang memiliki pengalaman lebih sedikit adalah mereka yang berusia lebih muda di mana mereka lebih berani dalam mengambil 
risiko untuk memperluas pasar asalkan dinilai memiliki peluang untuk memperoleh pendapatan yang lebih tinggi.

Tabel 2. Crosstabulation antara Faktor-Faktor Internal dan Pemilihan Pasar Petani Mangga

\begin{tabular}{|c|c|c|c|c|c|c|c|c|c|}
\hline & \multicolumn{7}{|c|}{ Tujuan Pasar (\%) } & \multirow{3}{*}{ Jumlah (\%) } \\
\hline & & \multicolumn{2}{|c|}{1 Tujuan } & \multicolumn{3}{|c|}{2 Tujuan } & \multicolumn{2}{|c|}{3 Tujuan } & \\
\hline & & $\mathrm{A}$ & $\mathrm{B}$ & $\mathrm{C}$ & $\mathrm{D}$ & $\bar{E}$ & $\mathrm{~F}$ & $\mathrm{G}$ & \\
\hline \multirow{4}{*}{ Umur (Tahun) } & $31-45$ & 0 & 22 & 0 & 4 & 4 & 0 & 2 & 32 \\
\hline & $46-64$ & 4 & 30 & 4 & 2 & 6 & 2 & 0 & 48 \\
\hline & $\geq 65$ & 0 & 20 & 0 & 0 & 0 & 0 & 0 & 20 \\
\hline & Jumlah & 4 & 72 & 4 & 6 & 10 & 2 & 2 & 100 \\
\hline Pengalaman & $<10$ & 2 & 0 & 0 & 4 & 8 & 0 & 0 & 14 \\
\hline Usahatani & $10-20$ & 2 & 70 & 4 & 2 & 2 & 2 & 2 & 84 \\
\hline \multirow[t]{2}{*}{ Mangga (Tahun) } & $>20$ & 0 & 2 & 0 & 0 & 0 & 0 & 0 & 2 \\
\hline & Jumlah & 4 & 72 & 4 & 6 & 10 & 2 & 2 & 100 \\
\hline \multirow{6}{*}{$\begin{array}{l}\text { Tingkat } \\
\text { Pendidikan }\end{array}$} & Tidak Sekolah & 0 & 2 & 0 & 0 & 0 & 0 & 0 & 2 \\
\hline & SD & 0 & 62 & 4 & 6 & 4 & 0 & 0 & 76 \\
\hline & SMP & 0 & 4 & 0 & 0 & 2 & 0 & 0 & 6 \\
\hline & SMA & 4 & 4 & 0 & 0 & 2 & 2 & 2 & 14 \\
\hline & Akademi/Diploma & 0 & 0 & 0 & 0 & 2 & 0 & 0 & 2 \\
\hline & Jumlah & 4 & 72 & 4 & 6 & 10 & 2 & 2 & 100 \\
\hline Jumlah & $0-150$ & 0 & 52 & 0 & 6 & 0 & 0 & 2 & 60 \\
\hline Kepemilikan & $151-300$ & 2 & 16 & 0 & 0 & 4 & 0 & 0 & 22 \\
\hline \multirow[t]{2}{*}{ Pohon Mangga } & $>300$ & 2 & 4 & 4 & 0 & 6 & 2 & 0 & 4 \\
\hline & Jumlah & 4 & 72 & 4 & 6 & 10 & 2 & 2 & 100 \\
\hline \multirow{4}{*}{$\begin{array}{c}\text { Tingkat } \\
\text { Kepercayaan }\end{array}$} & Rendah & 0 & 18 & 2 & 2 & 2 & 0 & 0 & 24 \\
\hline & Tinggi & 4 & 54 & 2 & 4 & 8 & 2 & 2 & 76 \\
\hline & Jumlah & 4 & 72 & 4 & 6 & 10 & 2 & 2 & 100 \\
\hline & Sulit & 2 & 48 & 0 & 6 & 8 & 0 & 0 & 64 \\
\hline \multirow[t]{3}{*}{ Akses Informasi } & Cukup & 2 & 24 & 4 & 0 & 0 & 0 & 2 & 32 \\
\hline & Mudah & 0 & 0 & 0 & 0 & 2 & 2 & 0 & 4 \\
\hline & Jumlah & 4 & 72 & 4 & 6 & 10 & 2 & 2 & 100 \\
\hline \multirow{5}{*}{$\begin{array}{l}\text { Kepemilikan } \\
\text { Alat } \\
\text { Transprotasi }\end{array}$} & Tidak memiliki & 0 & 32 & 0 & 0 & 0 & 0 & 0 & 32 \\
\hline & Milik & 0 & 40 & 2 & 0 & 2 & 2 & 0 & 46 \\
\hline & Sewa & 4 & 0 & 0 & 0 & 6 & 0 & 2 & 12 \\
\hline & Milik dan Sewa & 0 & 0 & 2 & 6 & 2 & 0 & 0 & 10 \\
\hline & Jumlah & 4 & 72 & 4 & 6 & 10 & 2 & 2 & 100 \\
\hline \multirow{4}{*}{$\begin{array}{l}\text { Keaktifan dalam } \\
\text { Kelompok Tani }\end{array}$} & 1-2 kali/bulan & 4 & 24 & 2 & 0 & 0 & 0 & 0 & 30 \\
\hline & 1-2 kali/tahun & 0 & 40 & 2 & 6 & 8 & 2 & 2 & 60 \\
\hline & $>2 \mathrm{kali} / \mathrm{tahun}$ & 0 & 8 & 0 & 0 & 2 & 0 & 0 & 10 \\
\hline & Jumlah & 4 & 72 & 4 & 6 & 10 & 2 & 2 & 100 \\
\hline \multirow{3}{*}{$\begin{array}{l}\text { Keaktifan } \\
\text { Mengikuti } \\
\text { Penyuluhan } \\
\end{array}$} & 1-2 kali/bulan & 0 & 16 & 0 & 0 & 0 & 2 & 0 & 18 \\
\hline & 1-2 kali/tahun & 4 & 56 & 4 & 6 & 10 & 0 & 2 & 82 \\
\hline & Jumlah & 4 & 72 & 4 & 6 & 10 & 2 & 2 & 100 \\
\hline
\end{tabular}

Ket: 1 Tujuan (A dan B); A = Pedagang Besar; B = Tengkulak/Pedagang pengumpul; 2 Tujuan (C, D dan E); $\mathrm{C}=$ Pedagang besar, Pasar tradisional; $\mathrm{D}=$ Tengkulak/Pedagang pengumpul, Pasar tradisional; E $=$ Tengkulak/Pedagang pengumpul, Pedagang besar; 3 Tujuan $(\mathrm{F}$ dan $\mathrm{G}) ; \mathrm{F}=$ Pedagang besar, Eksportir, Pedagang, Pengecer; $\mathrm{G}=$ Tengkulak/ Pedagang pengumpul, Pedagang besar, Pasar tradisional.

Sumber: Analisis Data Primer (2020) 
Maina (2015) menyatakan bahwa petani yang memiliki pengalaman lebih lama cenderung menghindari penjualan ke kelompok dan langsung menjual ke individu. Dengan lamanya pengalaman usahatani, biaya transaksi terkait informasi pencarian pasar, negosiasi, dan pelaksanaan kontrak pun dapat dikurangi. Keadaan ini sesuai dengan petani mangga di Kecamatan Sedong dengan pengalaman usahatani yang cukup lama cenderung menjual hanya kepada satu pembeli (Tabel 2). Hal ini dikarenakan petani telah mendapat pasar yang pasti dan telah nyaman menjalin kemitraan dengan pihak tersebut yang juga dilandasi dengan hubungan kebiasaan. Di samping itu, petani dengan berpengalaman usahatani mangga lebih lama pada kenyataannya tidak diiringi dengan kemampuan petani mengakses informasi pasar yang lebih luas karena hanya fokus melakukan kegiatan usahatani yang dilakukan secara berulang, tanpa adanya inovasi dalam pemasaran.

\section{Tingkat pendidikan}

Harahap dkk. (2018) menyatakan bahwa tingkat pendidikan tidak mempengaruhi petani dalam memilih saluran pemasaran. Berbeda halnya dengan petani mangga di Kecamatan Sedong, tingkat pendidikan justru memiliki hubungan yang berbanding lurus terhadap pemilihan pasar oleh petani mangga. Hubungan berbanding lurus menunjukkan bahwa semakin tinggi pendidikan petani, pasar yang dituju oleh petani akan semakin banyak. Petani yang berpendidikan lebih tinggi akan lebih mudah memahami dinamika yang terjadi di pasar.

Menurut Maina (2015), petani yang berpendidikan lebih tinggi akan memilih pasar selain kepada tengkulak/pedagang pengumpul. Begitu juga halnya dengan petani di Kecamatan Sedong bahwa petani yang berpendidikan lebih tinggi telah mengetahui bahwa setiap pembeli memiliki kedudukan yang berbeda pada saluran pemasaran. Mereka menyadari bahwa menjual kepada pihak selain tengkulak dapat memotong rantai pasok, sehingga pendapatan yang diperoleh pun akan semakin lebih besar.

Berdasarkan Tabel 2, mayoritas tingkat pendidikan petani mangga yang berada di Kecamatan Sedong adalah SD. Pihak pembeli yang dituju pun hanya tengkulak/pedagang pengumpul. Hal ini dikarenakan umumnya petani mangga di Kecamatan Sedong yang memiliki pendidikan terakhir SD adalah mereka yang berusia tua di mana memiliki motivasi yang rendah untuk memperluas 
pasar. Menurut Azizah dkk. (2019), petani berpendidikan rendah cenderung tidak melakukan eksplorasi terhadap inovasi teknologi budidaya maupun pemasaran, sehingga kegiatan usahatani mangga yang dilakukan hanya berdasarkan kebiasaan dan tidak berani mengambil risiko.

\section{Jumlah pohon}

Jumlah pohon memiliki hubungan yang berbanding lurus dengan pemilihan pasar bagi petani mangga. Semakin banyak jumlah pohon yang dimiliki, pasar yang dituju oleh petani pun akan semakin banyak. Jumlah pohon mangga yang banyak akan berbanding lurus dengan tingkat produktivitas yang dihasilkan. Permintaan pasar yang beragam pun membuat petani menjadi lebih mudah untuk dapat menjual hasil panen kepada berbagai pembeli sesuai dengan kondisi mangga yang akan dipasoknya.

Menurut Muthini (2017), petani dengan jumlah pohon mangga yang banyak cenderung memilih menjual kepada eksportir, sedangkan menurut Honja (2017), petani yang memiliki jumlah pohon yang banyak lebih memilih untuk menjual kepada pedagang besar. Pada kenyataannya, hanya $2 \%$ petani yang mampu menjual kepada eksportir dan $4 \%$ petani mangga yang hanya menjual kepada pedagang besar adalah mereka yang memiliki 151-450 pohon mangga (Tabel 2). Penyebab petani mangga lainnya yang tidak dapat menjual kepada eksportir adalah masih terdapat hama lalat buah pada hasil panen mangganya.

Semakin banyaknya jumlah pohon yang dimiliki oleh petani mangga di Kecamatan Sedong, mereka cenderung untuk menjadikan pedagang besar sebagai pembeli pilihan pertamanya. Hal ini dikarenakan pedagang besar menerima kondisi mangga dalam grade A/B tanpa perlu sortasi yang ketat dan setiap pedagang besar saling bersaing untuk menawarkan harga yang tinggi. Semetara itu, petani mangga dengan jumlah pohon yang lebih sedikit cenderung untuk menjual kepada tengkulak. Setiap petani mangga tersebut umumnya hanya bermitra dengan satu tengkulak dan bersedia untuk menerima harga yang rendah, baik ketika musim panen raya ataupun menjual saat kualitas mangga sedang rendah. Dengan jumlah pohon mangga yang sedikit, petani mangga akan terbatas dalam memperluas pasarnya hal ini dikarenakan setiap pembeli akan menuntut kontinuitas 
terhadap kuantitas dan kualitas mangga yang dipasoknya.

\section{Tingkat kepercayaan}

Tingkat kepercayaan dilihat dari keinginan petani untuk tetap atau mengganti mitra yang dipilihnya selama melakukan penjualan hasil panen mangga. Adegbola \& Gardebroek (2007) menyatakan bahwa petani yang lebih tua tidak percaya kepada pasar selain tengkulak karena telah membentuk hubungan jangka panjang. Sementara menurut Rachmah dkk. (2019), tingkat kepercayaan merupakan faktor yang signifikan dalam memilih pasar di mana tengkulak adalah pembeli yang dianggap petani tidak dapat diandalkan karena transaksi jual beli mangga hanya didasari oleh kontrak secara lisan. Namun pada kenyataannya, tingkat kepercayaan tidak memiliki keterkaitan dengan pemilihan pasar bagi petani mangga di Kecamatan Sedong.

Apabila dilihat dari Tabel 2, tinggi atau rendahnya tingkat kepercayaan petani mangga di Kecamatan Sedong ternyata tidak mempengaruhinya dalam memperluas pasar atau menambah jenis pasar. Hal ini dikarenakan petani cenderung untuk percaya hanya kepada satu jenis pasar. Misalnya ketika petani merasa ditipu oleh tengkulak dalam menjual hasil panen mangga, petani hanya berusaha untuk mencari tengkulak lain, bukan beralih menjual kepada pembeli lain, seperti pedagang besar atau pasar tradisional. Selain itu, alasan petani ingin mengganti mitra adalah jika menemukan mitra lain yang menawarkan harga jual yang lebih tinggi, tetapi tetap pada jenis pasar yang sama.

\section{Akses informasi}

Kategori rendah, sedang, tinggi pada akses informasi ditentukan dari banyaknya sumber informasi yang diperoleh petani terkait harga jual mangga, yaitu informasi dari petani mangga, pasar, media elektronik, dan survey langsung ke ritel modern. Akses informasi tidak memiliki keterkaitan dengan pemilihan pasar bagi petani mangga di Kecamatan Sedong. Hal ini dikarenakan seluruh petani umumnya memang mendapatkan informasi dari teman sesama petani mangga dan pihak pembeli, baik petani yang hanya menjual kepada satu tujuan pasar ataupun lebih.

Berdasarkan Tabel 2, petani yang memperoleh akses informasi pasar dengan kategori mudah mampu menjual kepada 2-3 tujuan pasar. Sementara petani yang mengakses informasi pasar secara sulit maupun cukup pada umumnya hanya mampu menjual kepada 
tengkulak/pedagang pengumpul. Hal tersebut dikarenakan petani hanya mengandalkan informasi dari temannya yang merupakan petani mangga dan pihak tengkulak/ pedagang pengumpul, sehingga tidak mampu menjangkau pasar yang lebih luas karena para petani mangga tersebut hanya menjual mangga berdasarkan kebiasaan atau rutinitas sehari-hari.

Menurut Maina (2015), petani yang menjual melalui saluran pasar lokal harus menghabiskan banyak waktu untuk mencari pembeli karena mereka tidak yakin tentang keadaan pasar, sedangkan petani yang berjualan melalui tengkulak menghabiskan waktu lebih sedikit karena tengkulak yang memiliki tanggung jawab penuh dalam mencari pembeli akhir. Apabila dilihat dari keadaan di Kecamatan Sedong, informasi harga umumnya diperoleh hanya saat penentuan harga jual mangga. Banyak atau sedikitnya informasi yang diakses petani tidak menentukan petani akan mendapatkan pasar yang lebih luas karena informasi pasar hanya dipergunakan dalam menentukan harga jual, bukan dimanfaatkan oleh petani agar memiliki posisi yang lebih kuat dalam pasar, sehingga dapat menjual mangga kepada berbagai pembeli dengan harga jual yang bervariasi.

\section{Kepemilikan transportasi}

Kepemilikan transportasi memiliki hubungan yang berbanding lurus dengan pemilihan pasar. Semakin banyak jumlah dan jenis transportasi yang dimiliki, pasar yang dituju semakin beragam. Mzyece (2011) menyatakan bahwa petani yang memiliki transportasi akan lebih mudah untuk mengakses pasar yang lebih jauh di mana dapat memperoleh harga jual yang lebih tinggi, bahkan setelah dikurangi dari biaya transportasi.

Berdasarkan Tabel 2, sebanyak $40 \%$ responden yang memiliki kendaraan menjual kepada tengkulak/pedagang pengumpul. Petani mangga di Kecamatan Sedong umumnya hanya memiliki transportasi berupa motor yang hanya bertujuan untuk mempermudah pengiriman jarak dekat, yaitu dari rumah petani ke rumah pedagang pengumpul. Akan tetapi, petani yang memiliki mobil pick up cenderung memilih untuk menjual kepada pembeli berupa pedagang besar, pasar tradisional, ritel modern, dan eksportir yang berada di luar daerah.

Makhura (2002) dan Olwande et al (2010) mengindikasikan bahwa kepemilikan transportasi secara 
signifikan mempengaruhi keputusan untuk berpartisipasi dalam pasar karena berkurangnya biaya transaksi yang terkait dengan biaya transportasi. Namun, jika biaya transaksi sangat tinggi, kepemilikan alat transportasi mungkin tidak memengaruhi keputusan untuk berpartisipasi dalam pasar (Jagwe, 2010). Dengan demikian, petani di Kecamatan Sedong yang telah berpeluang untuk bermitra dengan pedagang besar, pasar tradisional, dan ritel modern akan berusaha untuk memperoleh transportasi dengan cara sewa pick up mengingat keterbatasan modal yang dimiliki oleh petani mangga.

Petani yang tidak memiliki transportasi dan tidak memiliki biaya untuk menyewa transportasi cenderung akan menjual hasil panennya kepada tengkulak. Hal ini dikarenakan para tengkulak/pedagang pengumpul di Kecamatan Sedong sebagian besar bersedia untuk melakukan transaksi jual beli mangga di rumah petani atau di lahan setelah melakukan panen. Apalagi ketika musim panen raya, banyak tengkulak yang berkeliling ke sekitar rumah petani mangga agar dapat memenuhi pasokannya. Namun, banyak petani yang tetap hanya menjual kepada satu tengkulak atau langganannya karena tengkulak baru yang berdatangan saat musim panen raya memberikan harga jual yang rendah.

\section{Keaktifan dalam kelompok tani}

Petani responden seluruhnya tergabung ke dalam kelompok tani. Setiap petani responden yang merupakan anggota kelompok tani selalu menghadiri kegiatan yang diadakan oleh kelompok tani, sehingga keaktifan dapat dilihat dari anggota kelompok tani yang satu dengan lainnya. Keaktifan dalam kelompok tani memiliki hubungan berbanding lurus dengan pemilihan pasar. Semakin aktif petani dalam menghadiri dan berpartisipasi pada kelompok taninya, pasar yang dituju pun akan lebih beragam. Hal ini dikarenakan salah satu fungsi kelompok tani adalah sebagai wadah untuk memperkuat hubungan antar petani mangga. Dengan adanya kelompok tani, petani juga memperoleh informasi mengenai pasar dari anggota lain maupun dipermudah dalam menjual kepada pedagang pengumpul yang juga berperan sebagai ketua kelompok tani.

Berdasarkan Tabel 2, sebanyak 60 $\%$ responden mengikuti kegiatan dalam kelompok tani setiap 1-2 kali/tahun. Anggota kelompok tani umumnya berkumpul pada suatu pendopo membahas budidaya dan pemasaran 
mangga. Selain itu, memaparkan masalah yang terjadi dalam melakukan usahatani mangga, misalnya terjadi pencurian hasil panen mangga pada petani yang memiliki lahan di dekat jalan raya. Kegiatan atau rapat yang diadakan oleh kelompok tani biasanya setiap musim mangga sedang berlangsung atau saat menjalankan teknologi off season.

Menurut Muthini et al (2017), petani yang tergabung dan aktif dalam kelompok tani cenderung menjual kepada eksportir di mana wakil dari kelompok tani akan melakukan negosiasi dengan eksportir setiap musimnya. Hal ini terjadi pada kelompok tani Sukamulya yang merupakan satu-satunya kelompok tani di Kecamatan Sedong yang telah mampu menjual kepada eksportir. Namun, sistem yang dilakukan berbeda. Anggota kelompok tani Sukamulya menjual kepada ketua poktan yang berperan sebagai pedagang pengumpul, sehingga keuntungan yang diperoleh seluruhnya untuk pedagang pengumpul, tidak disalurkan kepada kelompok tani. Sistem seperti ini juga berlaku pada ketua kelompok tani lainnya yang telah mampu bermitra dengan pembeli selain tengkulak, yaitu pedagang besar dan pasar tradisional.
Maina (2015) menyatakan bahwa petani yang menjual hasil panen mangga melalui kelompok tani akan mengurangi biaya transportasi karena para anggota kelompok tani melakukan patungan untuk menyewa alat transportasi. Berbeda halnya yang terjadi pada Kecamatan Sedong, petani mangga yang tergabung ke dalam kelompok tani tetap melakukan penjualan kepada ketua kelompok tani atau pembeli lainnya secara individu. Hal ini dikarenakan kelompok tani yang terdapat di Kecamatan Sedong hanya berfungsi sebagai wadah memperkuat hubungan antar anggota dan sarana pembelajaran terkait usahatani mangga, bukan sebagai penyalur hasil panen mangga yang siap untuk dijual.

\section{Keaktifan dalam mengikuti penyuluhan}

Menurut Saefudin dan Rasmikayati (2020), petani yang mengikuti penyuluhan akan lebih mampu menjual kepada eksportir karena memiliki kualitas produk yang lebih baik. Berbeda dengan pernyataan tersebut, keaktifan petani mangga di Kecamatan Sedong dalam mengikuti penyuluhan tidak memiliki keterkaitan dalam memilih pasar. Berdasarkan Tabel 2, tinggi atau rendahnya intensitas petani dalam mengikuti penyuluhan tidak memiliki 
pengaruh dalam memilih tujuan pasar yang lebih beragam. Hal ini dikarenakan seluruh petani mangga mengikuti penyuluhan yang diselenggarakan oleh Penyuluh Pertanian Lapangan (PPL).

Petani yang menjual kepada satu pembeli ataupun lebih akan memperoleh intensitas penyuluhan yang sama karena hal yang membedakan adalah intensitas penyuluhan antara kelompok tani. Setiap petani yang tergabung ke dalam kelompok tani secara rata memperoleh informasi yang diberikan, baik budidaya maupun pemasaran mangga. Akan tetapi, keadaan tersebut tidak menjamin bahwa setiap individu akan langsung mempraktikan dari informasi yang mereka terima. Dengan mengikuti penyuluhan, bukan berarti petani akan langsung memperoleh kualitas mangga yang lebih baik dan dapat menjangkau pasar yang lebih luas. Selain perubahan kesadaran petani untuk berkembang, keadaan ini juga tergantung kepada ketersediaan modal yang dimiliki petani untuk mengeluarkan biaya pemeliharaan maupun kemampuan petani dalam melakukan komunikasi yang dapat meyakinkan pihak pembeli agar dapat bersedia untuk bermitra dengannya.

\section{Hubungan antara Faktor Eksternal dengan Pemilihan Pasar Petani Mangga}

Faktor eksternal merupakan faktor yang dapat mempengaruhi suatu hal yang berasal dari luar diri pelaku. Faktor eksternal yang dimaksud dalam penelitian ini adalah faktor-faktor yang berasal selain dari dalam diri petani mangga, yaitu dapat dilihat dari kondisi pasar ataupun pihak-pihak lain yang berpengaruh bagi petani dalam menjual hasil panen mangga. Hubungan faktorfaktor eksternal dengan pemilihan pasar bagi petani mangga terangkum pada Tabel 3.

\section{Jarak ke pasar}

Jarak ke pasar memiliki hubungan yang berbanding lurus dengan pemilihan pasar. Semakin banyak pasar yang dituju, jarak total ke pasar pun akan semakin meningkat. Jarak yang ditempuh oleh petani dalam menjual hasil panen mangga kepada pembeli juga mempengaruhi keputusan mereka dalam pengadaan sarana transportasi, baik dengan membeli kendaraan pribadi atau menyewa. Petani mangga di Kecamatan Sedong yang menjual ke luar daerah umumnya menyewa pick up setiap melakukan pengiriman. 
Tabel 3. Crosstabulation antara Faktor-Faktor Eksternal dan Pemilihan Pasar Petani Mangga

\begin{tabular}{|c|c|c|c|c|c|c|c|c|c|}
\hline & \multicolumn{7}{|c|}{ Tujuan Pasar (\%) } & \multirow{3}{*}{ Jumlah (\%) } \\
\hline & & \multicolumn{2}{|c|}{1 Tujuan } & \multicolumn{3}{|c|}{2 Tujuan } & \multicolumn{2}{|c|}{3 Tujuan } & \\
\hline & & A & $\mathrm{B}$ & $\mathrm{C}$ & $\mathrm{D}$ & $\mathrm{E}$ & $\mathrm{F}$ & $\mathrm{G}$ & \\
\hline \multirow{5}{*}{$\begin{array}{c}\text { Jarak ke pasar } \\
\quad(\mathrm{KM})\end{array}$} & $0-10$ & 4 & 72 & 0 & 0 & 8 & 0 & 0 & 84 \\
\hline & $11-20$ & 0 & 0 & 0 & 6 & 0 & 0 & 2 & 8 \\
\hline & $41-50$ & 0 & 0 & 2 & 0 & 0 & 0 & 0 & 2 \\
\hline & $>50$ & 0 & 0 & 2 & 0 & 2 & 2 & 0 & 6 \\
\hline & Jumlah & 4 & 72 & 4 & 6 & 10 & 2 & 2 & 100 \\
\hline \multirow{6}{*}{$\begin{array}{c}\text { Waktu tempuh } \\
\text { ke } \\
\text { pasar (Menit) }\end{array}$} & $0-20$ & 0 & 68 & 0 & 0 & 8 & 0 & 0 & 76 \\
\hline & $21-40$ & 0 & 4 & 0 & 0 & 0 & 0 & 2 & 6 \\
\hline & $41-60$ & 0 & 0 & 0 & 4 & 0 & 0 & 0 & 4 \\
\hline & $61-80$ & 4 & 0 & 0 & 2 & 0 & 0 & 0 & 6 \\
\hline & $>80$ & 0 & 0 & 4 & 0 & 2 & 2 & 0 & 8 \\
\hline & Jumlah & 4 & 72 & 4 & 6 & 10 & 2 & 2 & 100 \\
\hline \multirow{4}{*}{$\begin{array}{l}\text { Penyeleng- } \\
\text { garaan } \\
\text { penyuluhan }\end{array}$} & 1 kali/bulan & 0 & 16 & 0 & 0 & 2 & 2 & 0 & 20 \\
\hline & 1 kali/tahun & 0 & 14 & 0 & 6 & 0 & 0 & 0 & 20 \\
\hline & 2 kali/tahun & 4 & 42 & 4 & 0 & 8 & 0 & 2 & 60 \\
\hline & Jumlah & 4 & 72 & 4 & 6 & 10 & 2 & 2 & 100 \\
\hline \multirow{5}{*}{$\begin{array}{l}\text { Kontribusi } \\
\text { pemerintah }\end{array}$} & Tidak ada & 0 & 32 & 0 & 0 & 0 & 0 & 0 & 2 \\
\hline & 3-5 tahun sekali & 0 & 40 & 2 & 0 & 0 & 0 & 0 & 12 \\
\hline & $1 \mathrm{kali} / \mathrm{tahun}$ & 4 & 0 & 0 & 0 & 4 & 2 & 2 & 72 \\
\hline & 2 kali/tahun & 0 & 6 & 0 & 0 & 6 & 0 & 2 & 14 \\
\hline & Jumlah & 4 & 72 & 4 & 6 & 10 & 2 & 2 & 100 \\
\hline
\end{tabular}

Ket: 1 Tujuan (A dan B); A = Pedagang Besar; $\mathrm{B}=$ Tengkulak/Pedagang pengumpul; 2 Tujuan (C, D dan E); $\mathrm{C}=$ Pedagang besar, Pasar tradisional; $\mathrm{D}=$ Tengkulak/Pedagang pengumpul, Pasar tradisional; $\mathrm{E}$ $=$ Tengkulak/Pedagang pengumpul, Pedagang besar; 3 Tujuan $(\mathrm{F}$ dan $\mathrm{G}) ; \mathrm{F}=$ Pedagang besar, Eksportir, Pedagang, Pengecer; $\mathrm{G}=$ Tengkulak/ Pedagang pengumpul, Pedagang besar, Pasar tradisional.

Sumber: Analisis Data Primer (2020)

Berdasarkan Tabel 3, mayoritas petani mangga di Kecamatan Sedong yang menjual kepada tengkulak/pedagang pengumpul hanya berjarak 0-10 $\mathrm{km}$ dalam melakukan pengiriman hasil panen mangga. Dekatnya jarak antara petani dan pasar menjadi salah satu alasan bagi petani mangga untuk menjual kepada tengkulak/pedagang pengumpul. Hal ini dikarenakan petani hanya memiliki motor dan tidak mampu mengalokasikan biaya transportasi untuk sewa kendaraan lainnya. Selain itu, banyak tengkulak/pedagang pengumpul yang bersedia untuk datang ke rumah petani atau lahan dalam melakukan transaksi jual beli mangga. Keadaan tersebut menguntungkan bagi petani untuk menghemat biaya transportasi yang dikeluarkan olehnya.

Maina (2015) menyatakan semakin bahwa jarak ke pasar justru memiliki 
korelasi yang negatif bagi petani dalam memilih pasar. Petani cenderung memilih pasar yang jaraknya lebih dekat dengannya karena tidak perlu mengeluarkan biaya transportasi yang besar di mana dapat mempengaruhi pendapatan yang diperoleh baginya. Akan tetapi, terdapat juga petani mangga di Kecamatan Sedong yang telah menyadari bahwa dengan harga jual yang lebih tinggi yang ditawarkan oleh pihak pembeli dapat menutup biaya transportasi yang dikeluarkan, sehingga mereka bersedia untuk menjual hasil panennya hingga ke luar Kecamatan Sedong atau bahkan ke luar kota, seperti pasar induk di Jakarta.

\section{Waktu tempuh ke pasar}

Waktu tempuh ke pasar memiliki hubungan berbanding lurus dengan pemilihan pasar. Waktu tempuh berkaitan dengan jarak tempuh di mana semakin jauh jarak yang ditempuh oleh petani, waktu tempuh pun akan semakin bertambah. Dengan demikian, petani mangga yang memiliki tujuan pasar lebih banyak akan menghabiskan waktu yang lebih banyak dalam melakukan pengiriman mangga kepada pembeli.

Berdasarkan Tabel 3, mayoritas petani mangga di Kecamatan Sedong menghabiskan waktu selama 0-20 menit untuk bertemu dengan tengkulak/pedagang pengumpul dalam menjual hasil panen mangga. Hal ini dikarenakan para tengkulak yang langsung menemui para petani di rumah atau lahan. Sementara pedagang pengumpul yang dipilih oleh petani adalah ketua dari kelompok taninya yang juga merupakan tetangga.

Menurut Awaliyah dan Saefudin (2020), semakin panjang jarak yang ditempuh oleh petani, semakin besar juga kemungkinannya untuk mereka menjual ke pasar langsung. Hal ini dikarenakan opportunity cost antara mencukupi kebutuhan sehari-hari lebih besar dibandingkan waktu yang bersedia untuk dikeluarkan. Maka dari itu, petani mangga bersedia untuk menjual hingga ke luar daerah Kecamatan Sedong, bahkan ke daerah Jakarta di mana tingkat kemacetan yang tinggi yang akan memakan waktu lebih besar dibandingkan menjual hanya ke daerah sekitar karena telah menyadari bahwa harga jual pada tingkat pasar di luar daerah yang lebih tinggi, sehingga dapat meningkatkan pendapatan yang diperoleh.

\section{Penyelenggaraan penyuluhan}

Penyuluhan memberikan informasi yang bermanfaat bagi petani mangga, 
sehingga dapat mempermudahnya dalam membuat keputusan usahatani yang akan berpengaruh terhadap peningkatan produksi kualitas mangga (Rasmikayati dan Saefudin, 2015). Akan tetapi, penyelenggaraan penyuluhan tidak memiliki keterkaitan merupakan bagi petani di Kecamatan Sedong dalam memilih pasar. Berdasarkan Tabel 3, banyak atau sedikitnya penyuluhan yang diselenggarakan tidak menjamin petani mangga akan mendapatkan pasar yang lebih banyak dan lebih bervariasi. Hal ini dikarenakan penyuluhan diberikan secara rata oleh pihak PPL kepada setiap kelompok tani, sehingga yang membedakan adalah intensitas penyelenggaraan penyuluhan yang diberikan antar kelompok tani. Pihak penyuluh akan memberikan informasi kepada petani terkait budidaya dan pemasaran mangga, baik bagi petani yang hanya menjual kepada satu pembeli atapun lebih.

Setiap kelompok tani yang berada di Kecamatan Sedong mendapatkan penyuluh yang berbeda. Tempat penyuluhan yang diselenggarakan antara lain rumah petani yang dijadikan sebagai tempat berkumpul, pendopo, ataupun pada Taman Teknologi Pertanian (TTP) yang berada di dekat Setu Sedong.
Intensitas penyuluhan yang diberikan penyuluh juga berbeda. Terdapat satu kelompok tani bernama Sukamulya yang memperoleh penyuluhan setiap sebulan sekali. Hal ini dikarenakan poktan Sukamulya dinilai yang paling maju di Kecamatan Sedong dan memang berpotensi untuk semakin dikembangkan.

\section{Kontribusi pemerintah}

Kontribusi pemerintah yang diberikan kepada petani mangga antara lain bantuan modal berupa uang, pupuk, pestisida, zat perangsang bunga, sprayer, ataupun kendaraan motor beroda tiga. Setiap kelompok tani yang berada di Kecamatan Sedong memperoleh bantuan yang berbeda, yaitu tergantung keaktifan dari kegiatan yang dilakukan pada setiap kelompok tani dan dilihat dari kondisi kebutuhan yang diprioritaskan. Berdasarkan Tabel 3, sebanyak 72\% responden memperoleh bantuan setiap 1 kali/tahun. Pemberian bantuan umumnya dilakukan saat musim mangga sedang berlangsung, yaitu bulan November.

Kontribusi pemerintah memiliki hubungan yang berbanding lurus dengan pemilihan pasar. Semakin jarangnya kontribusi yang diberikan oleh pemerintah, tujuan pasar bagi petani mangga pun semakin sedikit. Hal ini dikarenakan kontribusi pemerintah 
menjadi salah satu sumber bagi petani dalam memperoleh modal untuk menjalankan usahatani. Apabila bantuan yang diberikan sedikit, petani tidak dapat memelihara pohon mangganya karena terhambat pada biaya pemeliharaan. Dengan demikian, produktivitas yang dihasilkan akan semakin sedikit dan tidak mampu memenuhi permintaan dari pasar.

Bantuan modal uang maupun input pertanian diberikan oleh pemerintah atau dinas setempat melalui ketua kelompok tani. Selanjutnya, ketua kelompok tani menyalurkan bantuan tersebut kepada para anggotanya ketika sedang mengadakan pertemuan. Menurut Pasaribu (2015), pemerintah memberikan bantuan tersebut bagi petani di Kecamatan Sedong agar dapat menerapkan Good Agricultural Practices (GAP) dengan baik, sehingga dapat meningkatkan produksi dan mutu buah mangga. Akan tetapi, penerapan GAP belum sepenuhnya dilakukan. Contohnya adalah pada kelompok tani Barokah yang berada di Desa Panongan, yang mana sebagian besar petani mangga menjual hasil panennya kepada tengkulak/pedagang pengumpul. Kesadaran mereka dalam upaya meningkatkan kualitas mangga masih rendah, sehingga potensi dalam memperluas pasar pun semakin rendah. Bahkan, ketua kelompok tani hingga berkorban mendatangkan ke rumah masing-masing anggota poktan dalam memberikan bantuan pemerintah.

\section{KESIMPULAN}

Faktor internal yang memiliki hubungan berbanding lurus dengan pemilihan pasar adalah tingkat pendidikan, jumlah pohon, kepemilikan transportasi, dan keaktifan dalam kelompok tani, sedangkan faktor internal yang memiliki hubungan berbanding terbalik dengan pemilihan pasar adalah umur dan pengalaman usahatani. Faktor eksternal yang memiliki hubungan berbanding lurus dengan pemilihan pasar adalah jarak ke pasar, waktu tempuh ke pasar, dan kontribusi pemerintah. Sementara faktor internal berupa tingkat kepercayaan, akses informasi, dan keaktifan dalam mengikuti penyuluhan, serta faktor eksternal berupa penyelenggaraan penyuluhan tidak memiliki hubungan dengan pemilihan pasar mangga di kecamatan Sedong.

\section{DAFTAR PUSTAKA}

Adegbola, P., \& Gardebroek, C. (2007). The effect of information sources on technology adoption and modification decisions. 
Agricultural Economics, 37(1), 5565 .

Anugrah, I. S. (2016). Mendudukkan komoditas mangga sebagai unggulan daerah dalam suatu kebijakan sistem agribisnis: upaya menyatukan dukungan kelembagaan bagi eksistensi petani. Awaliyah, F., \& Saefudin, B. R. (2020). Efisisensi Pemasaran Komoditas Mangga Gedong Gincu Di Kabupaten Cirebon. Paradigma Agribisnis, 3(1). DOI: http://dx.doi.org/10.33603/.v3i1.35 43.

Azizah, M. N., Rasmikayati, E., \& Saefudin, B. R. (2019). Perilaku budidaya petani mangga dikaitkan dengan lembaga pemasarannya di Kecamatan Greged Kabupaten Cirebon. Jurnal Ilmiah Mahasiswa Agroinfo Galuh, 5(1), 987-998. DOI:

http://dx.doi.org/10.25157/jimag.v5 i1.1447.

Deliana, Y. (2011). Analysis of Consumer Behavior on the Selection of Apple, Cytrus, Imported and Local Mango, in the Bandung City, West Java. Journal Lucrari Stiintifice. Seria Agronomie, 54(2), 32-37.

Elfadina, E. A., Rasmikayati, E., \& Saefudin, B. R. (2019). Analisis luas dan status penguasaan lahan petani mangga dikaitkan dengan perilaku agribisnisnya di Kecamatan Cikedung Kabupaten Indramayu. Jurnal Ilmiah Mahasiswa Agroinfo Galuh, 6(1), 69-79.

DOI:

http://dx.doi.org/10.25157/jimag.v6 i1.1376.

Harahap, J., Sriyoto, S., \& Yuliarti, E. (2018). Faktor-Faktor Yang Mempengaruhi Pengambilan Keputusan Petani Salak Dalam Memilih Saluran Pemasaran. Jurnal
AGRISEP Kajian Masalah Sosial Ekonomi Pertanian dan Agribisnis, 17(1), 95-106.

Honja, T., Geta, E., \& Mitiku, A. (2017). Determinants of market outlet choice of the smallholder mango producers: the case of Boloso Bombe Woreda, Wolaita Zone, Southern Ethiopia: a multivariate probit approach. Global Journal of Science Frontier Research, 17(2), 23-30.

Jagwe, J. N., Machethe, C. L., \& Ouma, E. (2010). Transaction costs and smallholder farmers' participation in banana markets in the Great Lakes Region of Burundi, Rwanda and the Democratic Republic of Congo.

Kusumo, R. A. B., Rasmikayati, E., Mukti, G. W., Fatimah, S., \& Saefudin, B. R. (2018). FaktorFaktor yang mempengaruhi keputusan petani mangga dalam menggunakan teknologi off season di Kabupaten Cirebon. Mimbar Agribisnis: Jurnal Pemikiran Masyarakat Ilmiah Berwawasan Agribisnis, 4(1), 57-69. Diakses melalui:

https://jurnal.unigal.ac.id/index.php /mimbaragribisnis/article/view/789.

Maina, C. M. (2015). Effect of transaction costs on choice of mango marketing channel and income of small-scale farmers in Makueni County, Kenya (Doctoral dissertation, Egerton University).

Makhura, M. T. (2002). Overcoming transaction costs barriers to market participation of smallholder farmers in the Northern Province of South Africa (Doctoral dissertation, University of Pretoria).

Marenya, P. P., \& Barrett, C. B. (2007). Household-level determinants of adoption of improved natural resources management practices 
among smallholder farmers in western Kenya. Food policy, 32(4), 515-536.

Mulyadi, M. (2011). Penelitian kuantitatif dan kualitatif serta pemikiran dasar menggabungkannya. Jurnal studi komunikasi dan media, 15(1), 128137.

Muthini, D. N., Nyikal, R. A., \& Otieno, D. J. (2017). Determinants of small-scale mango farmers market channel choices in Kenya: An application of the two-step Craggs estimation procedure. Journal of Development and Agricultural Economics, 9(5), 111-120.

Mzyece, A. (2011). Factors influencing cowpea producers' choice of marketing channels in Zambia. A research report for BSc Degree at University of Zambia, 46pp.

Olwande, P. O., Ogara, W. O., Okuthe, S. O., Muchemi, G., Okoth, E., Odindo, M. O., \& Adhiambo, R. F. (2010). Assessing the productivity of indigenous chickens in an extensive management system in southern Nyanza, Kenya. Tropical animal health and production, 42(2), 283-288.

Pariona, A. (2018). The Top Mango Producing Countries In The World. https://www.worldatlas.com/article s/the-top-mango-producingcountries-in-the-world.

Pasaribu, J. M. (2015). Pemanfaatan Informasi Teknologi oleh Petani Mangga. Tesis. Bogor: Institut Pertanian Bogor.

Rachmah, A. D., Rasmikayati, E., \& Saefudin, B. R. (2019). Factors related to continuation of mango cultivation. Jurnal Pertanian, 10(2), 52-60. DOI: http://dx.doi.org/10.30997/jp.v10i2. 1864.
Rasmikayati, E. (2018). Kajian Potensi dan Kendala dalam Proses Usahatani dan Pemasaran Mangga di Kabupaten Indramayu. Sosiohumaniora, 20(3), 215-221. DOI

https://doi.org/10.24198/sosiohuma niora.v20i3.15859.

Rasmikayati, E., \& Saefudin, B. R. (2018). Analisis Faktor-Faktor Yang Mampu Mendorong Petani Mangga Untuk Meningkatkan Perilaku Agribisnisnya Pada Era Globalisasi. Paradigma Agribisnis, 1(1), 1-13. DOI: http://dx.doi.org/10.33603/jpa.v1i1. 1491.

Rasmikayati, E., Elfadina, E. A., Kusumo, R. A. B., Saefudin, B. R., \& Supriyadi, S. (2020). Policy Analysis of Mango's Agribusiness Development (A Case in Cikedung District, Indramayu Regency). Jurnal Manajemen \& Agribisnis, 17(1), 52-52. DOI: https://doi.org/10.17358/jma.17.1.5 2.

Saefudin, B. R., Rasmikayati, E., Dwirayani, D., Awaliyah, F., \& Rachmah, A. R. A. (2020). Fenomena Peralihan Usahatani Mangga Ke Padi Di Kecamatan Sedong, Kabupaten Cirebon, Jawa Barat. Paradigma Agribisnis, 2(2). DOI:

http://dx.doi.org/10.33603/jpa.v2i2. 3156.

Sari, A. F., Rasmikayati, E., \& Saefudin, B. R. (2019). Behavioral Dynamics of Farmers and First Buyer in Marketing Mangoes in Sedong District, Cirebon Regency, West Java. Agrifor, 18(1), 63-72. DOI: https://doi.org/10.31293/af.v18i1.4 072. 